\title{
A tér szerepe az egyenlőtlenségek kutatásában Jegyzetek az MTA KRTK Regionális Kutatások Intézete társadalmi-térbeli egyenlőtlenségeket kutató horizontális mühelyének megalakulásához
}

\author{
The role of space in studying inequalities \\ Notes on the formation of the new horizontal group on \\ socio-spatial inequalities at the Institute for Regional \\ Studies, Centre for Economic and Regional Studies, \\ Hungarian Academy of Sciences
}

\author{
NAGY ERIKA, VIRÁG TÜNDE
}

\begin{abstract}
NAGY Erika: tudományos főmunkatárs, MTA Közgazdaság- és Regionális Tudományi Kutatóközpont, Regionális Kutatások Intézete, Békéscsaba; nagye@rkk.hu

VIRÁG Tünde: tudományos főmunkatárs, MTA Közgazdaság- és Regionális Tudományi

Kutatóközpont, Regionális Kutatások Intézete, Budapest; viragt@rkk.hu
\end{abstract}

Erika NAGY: senior research fellow, Institute for Regional Studies, Centre for Economic and Regional Studies, Hungarian Academy of Sciences, Békéscsaba; nagye@rkk.hu

Tünde VIRÁG: senior research fellow, Institute for Regional Studies, Centre for Economic and Regional Studies, Hungarian Academy of Sciences, Budapest; viragt@rkk.hu

2015 júniusában a hálózatosan, több telephellyel működő MTA KRTK Regionális Kutatások Intézete kutatóinak egy csoportja horizontális műhely létrehozását kezdeményezte. A közös munka fókuszában a társadalmi-térbeli egyenlőtlenségek, az azokat létrehozó-újratermelő folyamatok állnak. A mühely fórumot teremt az egyenlőtlenségek okait, mozgatórugóit boncolgató elméleti viták, a módszertani kísérletezés számára, az empirikus eredmények bemutatásához és a tudományetikai dilemmák megvitatásához is. A szerveződés az intézeten belüli személyes szakmai kapcsolatokra épült és jelenleg is így formálódik - így nem sajátja a tudományos élet intézményeire jellemző hierarchizáltság és nyitott a téma iránt érdeklődők számára. Ezért is tartjuk fontosnak céljainknak, a jövőbeli közös munka elméleti-koncepcionális kereteinek, és az eddig megfogalmazott kutatási feladatoknak a bemutatását.

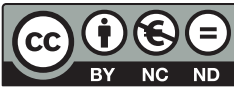




\section{Motivációk és célok}

A magyar társadalom egyik alapvető, a fennálló struktúrák stabilitását már középtávon is fenyegető problémája a társadalmi-térbeli egyenlőtlenségek mélyülése, újabb és újabb dimenzióinak megjelenése. A társadalom szegmentálódása, a szegénységben és kirekesztettségben élők társadalmi-demográfiai helyzetének mind súlyosabbá válása, valamint generációk közötti újratermelődésének felerősödése együtt jár e társadalmi csoportok térbeli koncentrálódásával. Azaz a térnek (urbánus, rurális, köz-, magán stb.) és a helynek (különösen a lakóhelynek) egyre erőteljesebb szerepe van a társadalmi egyenlőtlenségek alakításában. E folyamatok erősödésének és újratermelődésének egyszerre oka és következménye a gazdasági térszerkezet polarizálódása, a helyi közösségek környezetük (s általában a lokális terekhez kapcsolódó javak) fölötti ellenőrző szerepének elvesztése, s mind több, szélesebb társadalmi csoport kizáródása a közszolgáltatásokból. Mindez az utóbbi években napi gyakorlatokban megragadható valósággá, mindennapjaink részévé vált.

Hazai és nemzetközi kutatások sora foglalkozott a kelet-közép-európai térség rendszerváltozás óta formálódó, majd a legutóbbi válság óta egyre erőteljesebbé váló térbeli és társadalmi polarizációs folyamataival. Itthon azonban eddig kevesen vállalkoztak arra, hogy kritikai megközelítésben, a makrostruktúrák átrendeződéseit és a különböző cselekvők (csoportjaik) stratégiáit egyszerre vizsgálva, egyszerre több földrajzi léptékez kötődő térbeli folyamatként értelmezzék a társadalmi egyenlőtlenségek növekedését. Úgy véljük, ezzel is magyarázható, hogy a társadalom peremére szoruló csoportok, illetve a marginalizálódó terekben élők problémái nem kellő súllyal jelennek meg a hazai és az európai szakpolitikai vitákban és intézményi gyakorlatokban, újratermelve az egyenlőtlenségeket a globális és az európai piac keretei között, szubnacionális szinten és a lokális terekben is.

A műhelyhez csatlakozó kutatók alapvetően a társadalmi-térbeli egyenlőtlenségek létrejöttének, újratermelődésének feltárását, megértését és megismertetését tekintik feladatuknak. A tér és a társadalom viszonyának általunk javasolt - kölcsönös meghatározottságukat középpontba állító - újraértelmezésére építkezve az egyenlőtlenségeket létrehozó folyamatok átfogó, komplex és térbeli léptékeken átívelő vizsgálatára összpontosítunk, a makrostruktúrák átrendeződésétől a térbeli-intézményi hierarchiákon és a hálózati szerveződéseken át a lokális terekhez kötődő társadalmi gyakorlatokig.

Az egyenlőtlen térbeli fejlődést (makro)strukturális változások és a sajátos helyi-térségi fejlődés eredőjeként gondoljuk el, amihez elengedhetetlen a nyitott, tudományterületek határait átlépő kutatói gyakorlat. Az interdiszciplinaritásból következő elméleti és módszertani sokszínűség lehetővé teszi, hogy az egyenlőtlen térbeli fejlődés „tüneteit”, a sok esetben lokális terekhez kötődo problémákat, konfliktusokat egyszerre értelmezzük strukturális - globális, európai, nemzeti - beágyazottságukban és sajátos helyi, térségi, regionális fejlődés 
eredményeként. A térbeli-társadalmi egyenlőtlenségek átfogó, interdiszciplináris kutatása, a tér társadalmi szerepének újraértelmezése segítheti a hazai tudományos diskurzusok (át)alakítását, bekapcsolódásunkat a nemzetközi tudományos vitákba, a hazai és európai közbeszéd, illetve (szak)politikák alakításával pedig releváns válaszok keresését a társadalmi problémákra és helyi konfliktusokra.

Bár döntően alapkutatások keretei között megvalósítható-megválaszolható célokat, kérdéseket fogalmaztunk meg, nem szeretnénk elzárkózni attól, hogy a közjót szolgáló intézményi (szakpolitikai) gyakorlatokat segítő, illetve ezek strukturális átalakítását megalapozó kutatásokat végezzünk, s ezekkel segítsük a társadalmi-térbeli egyenlőtlenségek mérséklését - méltányosabb, igazságosabb társadalompolitika megvalósítását. A műhely kutatói mindezt eddigi tapasztalataikból - alap- és alkalmazott kutatásaikból - építkezve, a fennálló (globális, európai, nemzeti) intézményi-hatalmi struktúrák működésének és azok társadalmi-térbeli következményeinek kritikai elemzésével, a marginalizált csoportok és terek problémáinak megjelenítésével is igyekeznek segíteni.

\section{A közös munka elméleti-koncepcionális keretei}

A műhely résztvevői különböző tudományterületeket képviselnek, többségük a társadalomföldrajzhoz, szociológiához és közgazdaságtanhoz kötődik, más-más elméleti-koncepcionális keretek között és különböző kutatási módszereket alkalmazva foglalkoztak eddig a térbeli egyenlőtlenségek kutatásával. Ezt a sokszínűséget olyan értéknek tekintjük, amit meg kell őriznünk, s amelyet ki kell használnunk: például a hazai társadalomtudományban kevéssé elterjedt kvalitatív és kvantitatív módszerek egymást kiegészítő (együtt történő) alkalmazásával, az egy-egy diszciplínához köthető „mainstream” koncepciók kritikai értékelésével, a társadalmi-térbeli problémák, konfliktusok többirányú, komplex megközelítésével. Ugyanakkor kerestük és keressük azokat a koncepcionális elemeket, amelyek konzisztens keretet adhatnak a jövőbeli közös kutatásokhoz. Ezek eddig az alábbiakban körvonalazódtak:

- Közös munkánkban fontos helye, szerepe lesz az elméleti irányultságú kutatásoknak éppen úgy, mint a különböző módszerekkel végzett empirikus vizsgálódásnak. Mindez reflexív kutatómunkára ösztönöz - megközelítésünk, koncepciónk, kutatói gyakorlataink folytonos (újra-)értékelésére az egyenlőtlenségeket alakító ok-okozati viszonyok feltárása során.

- Kutatásainkat a társadalmi-térbeli folyamatokra, az egyenlőtlenségek kialakulására és újratermelődésére, ezek okainak, mechanizmusainak megértésére fókuszáljuk. Nem „pillanatképeket” alkotunk, hanem egyszerre értelmezzük ezeket történeti beágyazottságukban, a fennálló társadalmi (hatalmi) viszonyok részeként, s a strukturális változások és a 
társadalmi cselekvők stratégiái, akciói kölcsönhatásainak eredményeként. Mindez lehetővé teszi, hogy átfogó, ugyanakkor dinamikus és árnyalt képet alkossunk az egyenlőtlenségeket újratermelő társadalmi viszonyokról - s elkerüljük a tudományos és szakpolitikai diskurzusokban gyakran felbukkanó, dichotómiákra épülő érveléseket, amelyek önmagukban is hozzájárulhatnak a különbségek fennmaradásához.

- Olyan térkoncepciókra építkezünk, amelyek a teret társadalmi konstrukcióként értelmezik. A tér és a társadalom viszonya kölcsönösségen alapul; a tér nem csupán passzív befogadója, színtere a társadalmi folyamatoknak, hanem elválaszthatatlan része - egyszerre eszköze, eredménye, formálója - azoknak. Ennek megnyilvánulásai a hatalmi viszonyokat közvetítö-fenntartó térbeli hierarchiák éppen úgy, mint fizikai távolság, kirekesztés vagy éppen gazdasági alávetés eszközeként történő alkalmazása. Valójában nem is egyetlen térkoncepcióról van szó, hanem a tér és társadalom viszonyának korábbiaktól eltérő értelmezéséről, amely lehetővé teszi sokféle megközelítés, koncepció összekapcsolását és sokszínű módszertan alkalmazását a közös kutatások keretei között. Ezekben fontos szerepet kaphatnak a térbeli-társadalmi struktúrák átrendeződésére irányuló kvantitatív vizsgálatok, a külső és belső vállalati kapcsolatrendszereket vagy a lokális közösségek müködését elemző hálózatkutatások éppúgy, mint a társadalmi diskurzusok elemzése és a mikroszociológai módszerek. A résztvevők által elfogadott és használt, térbeli egyenlőtlenségeket magyarázó koncepciók közül a különböző centrumperiféria értelmezések, a marginalitáskoncepciók, az egyenlőtlen fejlődés, illetve a tértermelés lefebvre-i magyarázata, a társadalmi tőke különböző értelmezései, továbbá - a lokális kutatásokhoz kötődően - a mindennapi társadalmi gyakorlatokra fókuszáló posztstrukturalista, posztkolonialista, feminista áramlatokhoz kötődő elméletek, koncepciók kerültek előtérbe eddigi kutatásaink és első műhelyvitánk során. Ezek lehetséges szerepe, relevanciája, esetleges együttes alkalmazásuk a közeljövőben tervezett viták, panelbeszélgetések során kristályosodik ki.

\section{Közösen megvalósítható kutatási feladatok, tervek}

A műhely tagjai számos kutatási feladatot megfogalmaztak, amelyek rövid és középtávon meghatározhatják a közös munka irányát, illetve tematikáját. Ezek az alábbi nagyobb témák köré csoportosíthatóak:

- A társadalmi és a térbeli marginalizáció együttes - egymást erősítő hatásainak - vizsgálatakor, a társadalmi helyzetük, koruk, nemük, etnicitásuk és társadalmi megítélés szerinti fogyatékosságuk miatt a társadalom peremére szoruló csoportokhoz tartozók térformáló napi gyakorlatainak 
és diskurzusainak elemzésével feltárjuk, hogy térbeli mobilitásuk vagy annak hiánya hogyan befolyásolja régi és új lakóhelyeik társadalmi-gazdasági viszonyait, e településeknek az egyenlőtlen térbeli fejlődésben folyamatosan változó pozícióit. A több térbeli léptékre fókuszáló kutatásokban egyszerre vizsgáljuk a makrostrukturális átalakulásokat, azok lokális hatásait, az azokra adott válaszokat, különös tekintettel a következőkre. 1. A többségi társadalom által a marginalizált társadalmi csoportok számára kialakított és fenntartott helyek vizsgálatára, azaz a településen belüli térbeli kirekesztés változó mintáira, a kisváros-problematikára, a tanyás térségekhez, külterületekhez kötődő marginalitásra. 2. A leszakadó vidéki térségek komplex vizsgálatára, a gettósodó és hátrányos helyzetű térségek eltérő társadalomtörténeti és gazdasági múltjából fakadó különbözőségekre és hasonlóságokra. 3. A térségi vagy regionális egyenlőtlenségek vizsgálatára különböző dimenziók mentén (kvantitatív módszerekkel). 4. A társadalmi tőke szerepének vizsgálatára az egyenlőtlenségek alakításában, illetve a lokális/térségi válaszokban.

- A társadalmi marginalizálódást kutatásunkban a társadalmi integráció hiányaként, a társadalom egyes tagjai és csoportjai közötti gazdasági, kulturális és politikai távolság növekedéseként értelmezzük, amelyben kiemelt jelentősége van az állam, a területi vagy szubnacionális kormányzati és önkormányzati szervek által nyújtott közszolgáltatások szervezésének és elérhetöségének, azaz az igazgatási, oktatási, egészségügyi és szociális ellátások terén megjelenő egyenlőtlenségeknek. Ezért a lokális terekhez kötődő egyéni (vagy csoport)döntések, az intézményi gyakorlatok, továbbá az utóbbiakat formáló diskurzusok vizsgálatával arra is keressük a választ, hogy az állami alulfinanszírozottság és függőség, továbbá a piaci kiszolgáltatottság hogyan vezet a társadalmi-térbeli egyenlőtlenségek növekedéséhez.

- E folyamatokat erősíti és újratermeli a gazdasági térszerkezet polarizációja, amely Magyarországon a rendszerváltozás kezdete óta tartó folyamat, $\mathrm{s}$ egyes térségek tartós leszakadását, a helyi erőforrások és javak leértékelődését, ugyanakkor terekhez és helyekhez kötődő függőségi viszonyok kialakulását, illetve újratermelődését eredményezte. A gazdasági polarizáció és a függőségi viszonyok erősödésének vizsgálatát a periféria- és marginalizációkoncepciókból kiindulva elsősorban az alábbi problémákra fókuszálva gondoljuk el. 1. A befektetési döntések milyen vállalati lokalizációs stratégiákba, illetve tágabb intézményi kontextusba ágyazódnak, ezek megvalósulása a lokális terekben hogyan változtatja meg a társadalmi-gazdasági viszonyokat, s a marginalizált térségek gazdasági szereplői milyen válaszokat adhatnak kiszorított helyzetükre. 2. Az állam növekvő szerepe a helyi foglalkoztatásban, különös tekintettel a közfoglalkoztatás és az informális foglalkoztatás változó viszonyára, formáira, kontextusaira. 3. A fenti folyamatok a globális és európai 
beágyazottsága - Kelet-(Közép-)Európa mint félperiféria. 4. A gazdasági polarizációt erősítő szakpolitikai diskurzusok és intézményi gyakorlatok vizsgálata; azaz a területi egyenlőtlenségek kiegyenlítését célzó nemzeti és európai fejlesztéspolitikai diskurzusok és intézményi gyakorlatok miért nem vezettek a szubnacionális szintű különbségek mérséklődéséhez.

- A migrációs folyamatok társadalmi-térbeli egyenlőtlenségekre gyakorolt hatásának vizsgálata - makroszintű, térségi, illetve lokális, társadalmi gyakorlatokra fókuszáló kutatásokkal.

- Módszertani kérdések - a többféle módszertan együttes alkalmazásának, illetve a „bevett” módszerek új kontextusban vagy léptékben történő alkalmazásának tanulságai - megvitatása.

Reményeink szerint az MTA KRTK Regionális Kutatások Intézetének keretein belül formálódó, a társadalmi-térbeli egyenlőtlenségek problematikájára fókuszáló kutatóműhely a különböző intézetek és tudományterületek képviselői számára lehetőséget teremt, hogy a tér társadalmi szerepének újragondolásával a társadalmi-térbeli egyenlőtlenségek kutatásának újszerü elméleti és módszertani megközelítéseit alakítsák ki, ezzel formálják a hazai és nemzetközi tudományos diskurzusokat, és segítsék a releváns válaszok megfogalmazását. 